\title{
Optimasi formula sampo ekstrak daun pacar air (Impatiens balsamina L.) dengan kombinasi natrium lauril sulfat dan cocamide DEA
}

Dila Ayu Lestari1*, Yohanes Juliantoni1, Raisya Hasina1
${ }^{1}$ Program Studi Farmasi, Fakultas Kedokteran, Universitas Mataram, Mataram, Indonesia.

DOI: $\underline{\text { https:// doi.org/10.29303/sjp.v2i1.72 }}$

\section{Article Info}

Received : 2020-12-10

Revised : 2021-03-04

Accepted: 2021-04-28

\begin{abstract}
Dandruff is an anomalous condition characterized by excessive exfoliation of the horny layer from the scalp. The leaves of the water henna plant (Impatiens balsamina L.) are one of the natural ingredients that have anti-dandruff properties, so they can be used as an active ingredient in making dandruff shampoo. The water henna leaves were extracted using the maceration method with ethanol 96\%. Apart from the active ingredients, the shampoo also has an important component, namely surfactants. The surfactant used in this study was a combination of sodium lauryl sulfate and cocamide DEA. The purpose of this study was to optimize the surfactant formula of sodium lauryl sulfate and cocamide DEA in water henna leaf extract shampoo. This research was a laboratory experimental research. Formula optimization was done through the Simplex Lattice Design (SLD) method approach by making eight formulas. All formulas were evaluated for their physical properties including the foam height test and $\mathrm{pH}$ test. The data obtained were processed with Design Expert ${ }^{\circledR}$ software. Based on the physical evaluation of the water henna leaf extract shampoo, the results of the high foam test were $10,025 \mathrm{~cm}$ and a $\mathrm{pH}$ of 6,12 . The results of the acceptability test of shampoo preparations including the parameters of color, smell, texture, and viscosity received a fairly good response with the acquisition of values 3,1, 3,3, 3,9, and 4 with information 1 (very dislike), 2 (dislike), 3 (quite like), 4 (like) and 5 (really like). The optimum formula for the shampoo consisting of $5 \%$ water henna leaf extract, 1,1863\% sodium lauryl sulfate, 19,814\% cocamide DEA, 3\% CMC, 0,5\% citric acid, $0,5 \%$ methylparaben, $0,15 \%$ menthol, and distilled water had physical properties that meet the requirements of a good shampoo preparation.
\end{abstract}

Keywords: Shampoo, Simplex Lattice Design (SLD), water henna leaves

Citation: Lestari, D.A., Juliantoni, Y., \& Hasina, R. (2020). Optimasi formula sampo ekstrak daun pacar air (Impatiens balsamina L.) dengan kombinasi natrium lauril sulfat dan cocamide DEA. Sasambo Journal of Pharmacy, 2(1), $23-31$. doi: https:// doi.org/10.29303/sjp.v2i1.72

\section{Pendahuluan}

Ketombe merupakan wujud pengelupasan sel kulit kepala yang berlebih ketika proses keratinisasi sel kulit kepala belum sempurna yang membentuk sisik putih dan menyebabkan kulit kepala menjadi kotor serta lepek dan berbau kurang sedap serta dapat menyebabkan kerontokan rambut (Maesaroh, 2016). Penyebab ketombe dapat berupa sekresi kelenjar keringat yang berlebihan atau adanya peranan mikroorganisme di kulit kepala yang menghasilkan suatu metabolit yang dapat menginduksi terbentuknya ketombe di kulit kepala (Mahataranti et al., 2012). Salah satunya adalah jamur Candida albicans (Anitha et al., 2015).

Salah satu bahan alam yang banyak ditemukan di Lombok dan pemanfaatannnya sebagai tanaman obat masih jarang adalah tanaman pacar air (Impatiens balsamina L.). Tanaman pacar air diketahui memiliki 
khasiat sebagai antiketombe. Berdasarkan penelitian yang telah dilakukan sebelumnya, efektivitas fraksi aquades dari ekstrak etanol daun pacar air dengan konsentrasi $5 \%$ menunjukkan adanya zona hambat yang terbentuk sebesar 13,83 $\mathrm{mm}$ terhadap pertumbuhan Candida albicans dengan metode difusi sumuran pada media PDA (Malonda et al., 2017). Dari penelitian yang telah dilakukan bahwa pada fraksi aquades ekstrak etanol daun pacar air mengandung senyawa flavonoid, kumarin, saponin dan kuinon (Sulistyaningrum et al., 2008). Flavonoid merupakan antimikroba dan saponin merupakan senyawa aktif yang dapat membunuh jamur Candida albicans (Robinson, 1995; Naitullah et al., 2014).

Berdasarkan penelitian yang dilakukan oleh Malonda et al., (2017) daun pacar air dapat dijadikan sebagai kandidat zat aktif dalam sampo antiketombe berbasis bahan alam dengan aktivitasnya yang dapat menghambat pertumbuhan jamur Candida albicans. Selain zat aktif, komponen yang berperan penting dalam sediaan sampo adalah surfaktan. Hal ini dikarenakan surfaktan merupakan kunci dari pembersih rambut, karena struktur molekulnya yang terdiri dari bagian hidrofilik dan lipofilik, memiliki kemampuan menurunkan tegangan permukaan antara air dan kotoran, sehingga kotoran tersuspensi dalam fase air (Emmawati et al., 2016). Surfaktan yang digunakan pada penelitian ini adalah kombinasi dari natrium lauril sulfat dan cocamide DEA.

Natrium lauril sulfat adalah salah satu surfaktan anionik yang memiliki daya pembersih dan memberikan busa. Pada konsentrasi 10\% natrium lauril sulfat dapat memberikan daya busa yang baik namun mengiritasi kulit. Iritasi ini dapat dihindari atau dikurangi dengan pemakaian kombinasi surfaktan sekunder nonionik. Surfaktan sekunder yang memiliki sifat tidak mengiritasi dan juga memiliki sifat meningkatkan viskositas dan membentuk busa lebih halus serta membentuk proses pelarutan adalah surfaktan cocamide DEA. Cocamide DEA bersifat tidak toksik, dapat memperbaiki penampilan dan meningkatkan stabilitas sediaan, serta memiliki kompaktibilitas yang baik terhadap kulit dan membran mukosa sehingga dapat digunakan pada kulit yang sensitif (Indrawati dan Nelly, 2011).

Variasi konsentrasi kombinasi surfaktan primer anionik dan surfaktan sekunder nonionik dibutuhkan untuk mencari konsentrasi kombinasi yang paling ideal. Sehingga dalam penelitian ini akan dilakukan optimasi surfaktan dari sediaan sampo yaitu natrium lauril sulfat dan cocamide DEA melalui pendekatan metode Simplex Lattice Design (SLD). Tujuan dari penelitian ini adalah untuk menentukan formula sampo yang optimum dan mengetahui hasil evaluasi formula optimum dari sediaan sampo ekstrak daun pacar air (Impatirns balsamina L.).

\section{Metode Penelitian Alat dan Bahan}

Alat-alat yang digunakan dalam penelitian ini ialah alat-alat gelas laboratorium (Iwaki), aluminium foil, ayakan, blender (Miyako), corong, gunting, hot plate (Labnet), kain hitam, kain mori, kertas label, kertas saring, kompor (Rinnai), lateks, lemari asam, masker, mortar, pH meter (Ohaus), pot $50 \mathrm{~mL}$, pot $100 \mathrm{~mL}$, rak tabung reaksi, rubber bulb, sendok besi, sendok plastik, spatula, termometer, timbangan analitik (Ohaus), toples kaca, toples plastik, wadah pengeringan, dan wajan. Adapun bahan-bahan yang digunakan yaitu daun pacar air (Impatiens balsamina L.) yang diambil di Desa Bunkate, Kecamatan Jonggat, Kabupaten Lombok Barat, Provinsi Nusa Tenggara Barat, etanol 96\% teknis (Merck), natrium lauril sulfat (Merck), cocamide DEA (Merck), CMC (Merck), mentol (Merck), asam sitrat (Merck), metil paraben (Merck), larutan $\mathrm{HCl} 2 \mathrm{~N}$ (Merck), akuades dan kertas perkamen.

\section{Pembuatan Simplisia dan Ekstrak Daun Pacar Air}

Daun pacar air terlebih dahulu dicuci dengan air mengalir untuk menghilangkan kotoran yang menempel. Daun Pacar air dikeringkan di bawah sinar matahari yang ditutupi dengan kain hitam. Sampel yang telah kering dihaluskan dengan menggunakan blender hingga menjadi serbuk yang halus (Malonda et al., 2017).

Ekstraksi daun Pacar air dilakukan dengan menggunakan metode maserasi. Sebanyak $500 \mathrm{~g}$ serbuk simplisia daun pacar air dimaserasi atau direndam dengan larutan etanol 96\% sebanyak $3.500 \mathrm{~mL}$ selama 24 jam dimana dilakukan pengadukan tiap jam pada 6 jam pertama. Setelah 24 jam, sampel disaring menggunakan kertas saring untuk memisahkan filtrat dan residu. Residu kemudian dilakukan remaserasi sebanyak 2 kali dengan proses yang sama.

Seluruh filtrat digabungkan menjadi satu, kemudian diuapkan pada suhu tidak lebih dari $50^{\circ} \mathrm{C}$ menggunakan wajan berisi air yang dipanaskan di atas kompor untuk memperoleh ekstrak kental. Ekstrak kental ditimbang dan disimpan dalam wadah gelas tertutup sebelum digunakan untuk pengujian.

\section{Uji Kandungan Saponin}

Ekstrak sebanyak $1 \mathrm{~g}$ dimasukkan ke dalam tabung reaksi lalu ditambahkan dengan $10 \mathrm{~mL}$ air panas. Tabung reaksi dikocok secara vertikal selama 10 detik kemudian ditambahkan 2 tetes $\mathrm{HCl} 2 \mathrm{~N}$. Jika terdapat buih setinggi 1-2 $\mathrm{cm}$ setelah didiamkan selama 10 menit maka larutan uji tersebut positif mengandung saponin (Marpaung dan Romelan, 2018). 


\section{Optimasi Formula Sampo Ekstrak Daun Pacar Air}

Berdasarkan formula sampo ekstrak daun pacar air pada tabel 1, maka akan dilakukan optimasi sampo ekstrak daun pacar air dengan variasi konsentrasi natrium lauril sulfat dan cocamide DEA. Variasi konsentrasi bahan tersebut diperoreh dari pengolahan data menggunakan perangkat lunak Design Expert versi 11.0.0 seperti pada tabel 2.

Tabel 1. Formula Sampo Ekstrak Daun Pacar Air

\begin{tabular}{ll}
\hline Bahan & Jumlah (\%) \\
\hline Ekstrak Daun Pacar Air & 5 \\
Natrium Lauryl Sulfat & $1-10$ \\
Cocamide DEA & $11-20$ \\
CMC & 3 \\
Asam Sitrat & 0,5 \\
Mentol & 0,5 \\
Metil Paraben & 0,15 \\
Akuades & ad 100 \\
\hline
\end{tabular}

Tabel 2. Variasi konsentrasi Natrium Lauril Sulfat dan Cocamide DEA

\begin{tabular}{lll}
\hline \multirow{2}{*}{ Formula } & \multicolumn{2}{c}{ Jumlah (\%) } \\
\cline { 2 - 3 } & $\begin{array}{l}\text { Natrium Lauril } \\
\text { Sulfat }\end{array}$ & Cocamide DEA \\
\hline 1 & 5,5 & 15,5 \\
2 & 10 & 11 \\
3 & 3,25 & 17,75 \\
4 & 7,75 & 13,25 \\
5 & 1 & 20 \\
6 & 10 & 11 \\
7 & 1 & 20 \\
8 & 5,5 & 15,5 \\
\hline
\end{tabular}

Pembuatan formula sampo dilakukan dengan tahap pertama yaitu mengembangkan CMC dengan air panas yang kemudian ditambahkan metil paraben yang telah dilarutkan dengan etanol dan juga ditambahkan cocamide DEA. Setelah itu diaduk sampai homogen dan ditambahkan dengan natrium lauril sulfat yang telah dilarutkan dengan air panas kemudian diaduk sampai homogen. Selanjutnya baru ditambahkan ekstrak daun pacar air dan diaduk sampai homogen kemudian ditambahkan asam sitrat yang telah dilarutkan dengan etanol dan diaduk sampai homogen. Setelah itu ditambahkan dengan mentol yang juga telah dilarutkan dengan etanol dan diaduk sampai homogen. Tahap terakhir yaitu penambahan akuades sampai cukup $50 \mathrm{~mL}$.

\section{Pembuatan Formula Optimum Sediaan Sampo}

Pembuatan sediaan sampo pada tahap ini dilakukan dengan menggunakan formula optimum yang telah didapatkan berdasarkan hasil optimasi sebelumnya. Sediaan sampo yang telah dibuat kemudian dievaluasi kembali sifat fisiknya yang meliputi uji organoleptik, pengukuran $\mathrm{pH}$, uji tinggi busa, dan uji akseptabilitas.
Verifikasi Formula Sampo Ekstrak Daun Pacar Air

Berdasarkan analisis menggunakan metode simplex lattice design (SLD) dengan perangkat lunak Design Expert versi 11.0.0. didapatkan satu formula optimum sampo ekstrak daun pacar air dengan prediksi respon formula yaitu respon tinggi busa dan $\mathrm{pH}$. Formula optimum yang didapatkan diverifikasi dengan cara membandingkan respon (tinggi busa dan $\mathrm{pH}$ ) hasil prediksi yang diperoleh dari perangkat lunak Design Expert versi 11.0.0. dengan hasil percobaan.

\section{Evaluasi Sifat Fisik Sampo Ekstrak Daun Pacar Air}

a) Uji Organoleptik

Uji organoleptis dilakukan dengan mengamati bentuk, bau, dan warna sediaan sampo ekstrak daun pacar air (Sitompul et al., 2016).

b) Pengukuran $\mathrm{pH}$

Sampo sebanyak $1 \mathrm{~g}$ dilarutkan kedalam $10 \mathrm{~mL}$ air dan diukur $\mathrm{pH}$ nya dengan menggunakan $\mathrm{pH}$ meter digital (Sitompul et al., 2016).

c) Uji Tinggi Busa

Sampo ekstrak daun pacar air sebanyak 0,1 g dilarutkan dalam $10 \mathrm{~mL}$ air. Kemudian dimasukkan ke dalam tabung reaksi, ditutup dan dikocok selama 20 detik dengan cara membalikkan tabung reaksi secara beraturan. Kemudian diukur tinggi busa yang terbentuk (Sitompul et al., 2016).

d) Uji Akseptabilitas

Uji akseptabilitas dilakukan terhadap 20 orang sukarelawan dengan menggunakan angket. Pengujian dilakukan dengan meminta tanggapan sukarelawan terhadap sediaan sampo ekstrak daun pacar air. Tanggapan yang diminta berupa warna, aroma, tekstur dan kekentalan. Sukarelawan memberikan skor penilaian dari angka 1-5 dengan keterangan 1 (sangat tidak suka), 2 (tidak suka), 3 (cukup suka), 4 (suka) dan 5 (sangat suka) (Astuti et al., 2017).

\section{Analisis Data}

Penentuan formula optimum dilakukan dengan metode Simplex Lattice Design (SLD) menggunakan perangkat lunak Design Expert versi 11.0.0. Parameter yang diamati meliputi $\mathrm{pH}$ dan tinggi busa yang kemudian diolah untuk menentukan koefisien $\mathrm{a}, \mathrm{b}$ dan ab sehingga didapatkan persamaan sebagai berikut:

$\mathrm{Y}=\mathrm{a}(\mathrm{A})+\mathrm{b}(\mathrm{B})+\mathrm{ab}(\mathrm{AB})$

Keterangan :

$\mathrm{Y}=$ Hasil penelitian ( $\mathrm{pH}$, tinggi busa)

$\mathrm{A}=$ Kadar proporsi komponen $\mathrm{A}$

B $=$ Kadar proporsi komponen B

Dibuat persamaan Simplex Lattice Design (SLD) dan ditentukan contour plot yang diinginkan (Susanto, 2008). Selanjutnya data hasil optimasi dilakukan verifikasi formula dengan analisis statistik one sample ttest menggunakan program perangkat lunak SPSS versi 16.0. 


\section{Hasil dan Pembahasan \\ Pengambilan Sampel}

Sampel daun pacar air (Impatiens balsamina L.) diambil di Desa Bunkate, Kecamatan Jonggat, Kabupaten Lombok Barat, Provinsi Nusa Tenggara Barat. Daun pacar air yang dipanen adalah daun yang sudah tua dari tanaman yang sudah dewasa. Daun pacar air dipanen dengan cara dipetik secara manual satu per satu. Tanaman pacar air yang dipanen adalah tanaman yang utuh dan sehat. Tanaman yang terinfeksi jamur atau serangga tidak dipanen karena produk organisme tersebut dapat mengubah profil kandungan senyawa fitokimia bahkan menghasilkan racun (Balai Besar Litbang Tanaman Obat dan Obat Tradisional, 2011).

\section{Pembuatan Simplisia Daun Pacar Air}

Daun pacar air sebanyak $7 \mathrm{~kg}$ dicuci dengan air mengalir untuk menghilangkan kotoran yang menempel. Kemudian, daun pacar air dikeringkan di bawah sinar matahari dengan ditutupi kain hitam. Hal ini bertujuan untuk menyaring sinar ultraviolet yang mungkin dapat merusak kandungan berkhasiat dari simplisia tersebut (Sudewo, 2009). Pengeringan dilakukan untuk mengurangi kadar air dan menghentikan reaksi enzimatik yang dapat merusak atau menurunkan mutu simplisia (Suharmiati dan Herti, 2003). Daun pacar air kering kemudian dihaluskan menggunakan blender hingga menjadi serbuk yang halus. Serbuk halus daun pacar air yang didapatkan sebanyak $646 \mathrm{~g}$.

\section{Pembuatan Ekstrak Daun Pacar Air}

Ekstraksi daun Pacar air dilakukan dengan menggunakan metode maserasi dengan pelarut etanol $96 \%$. Keuntungan metode maserasi yaitu dapat mengekstraksi sampel dalam jumlah banyak dan menjaga senyawa yang bersifat termolabil dari kerusakan akibat panas (Doughari, 2006). Pelarut etanol 96\% digunakan karena dapat menyari hampir keseluruhan kandungan senyawa metabolit sekunder baik nonpolar, semi polar maupun polar (Iswanti, 2009). Ekstrak kental dan Rendemen ekstrak yang diperoleh yaitu sebanyak $94,93 \mathrm{~g}$ dan $18,989 \%$.

\section{Uji Kandungan Saponin}

Uji kandungan saponin dilakukan untuk memastikan adanya saponin dalam ekstrak daun pacar air (Impatiens balsamina L.) melalui uji busa. Adapun hasil uji kandungan ekstrak daun pacar air yang diperoleh yaitu positif. Berdasarkan uji kualitatif didapatkan bahwa pada sampel ekstrak daun pacar air membentuk busa stabil dengan ketinggian $1 \mathrm{~cm}$ sehingga sampel ekstrak daun pacar air dikatakan positif mengandung saponin.

Dasar hasil uji busa adalah sifat senyawa saponin yang mudah larut dalam air dan menimbulkan busa ketika dikocok. Busa terbentuk karena saponin merupakan senyawa yang mempunyai gugus hidrofil dan hidrofob. Pada saat dikocok, gugus hidrofil akan berikatan dengan air sedangkan gugus hidrofob berikatan dengan udara sehingga membentuk buih. Pemberian $\mathrm{HCl} 2 \mathrm{~N}$ untuk menambah kepolaran sehingga gugus hidrofil akan berikatan lebih stabil dan buih yang terbentuk menjadi stabil (Simaremare, 2014).

\section{Formulasi Sediaan Sampo Ekstrak Daun Pacar Air}

Pada penelitian ini sediaan sampo dengan berbagai konsentrasi surfaktan dibuat dengan menggunakan bahan aktif yaitu ekstrak daun pacar air dengan konsentrasi 5\%, surfaktan serta bahan tambahan. Konsentrasi 5\% ini didapatkan berdasarkan penelitian yang telah dilakukan sebelumnya oleh Malonda et al., (2017) yang menyatakan bahwa pada konsentrasi tersebut ekstrak daun pacar air dapat menghambat jamur candida albicans yang merupakan salah satu jamur penyebab terjadinya ketombe. Kandungan dari ekstrak daun pacar air yang diduga memiliki efektivitas sebagai antijamur tersebut adalah saponin. Saponin mempunyai tingkat toksisitas yang tinggi terhadap fungi. Mekanisme kerja saponin sebagai antifungi berhubungan dengan interaksi saponin dengan sterol membran. Senyawa saponin berkontribusi sebagai antijamur dengan mekanisme menurunkan tegangan permukaan membran sterol dari dinding sel jamur sehingga permeabilitasnya meningkat. Permeabilitas yang meningkat mengakibatkan cairan intraseluler yang lebih pekat tertarik keluar sel sehingga nutrisi, zat-zat metabolisme, enzim, dan protein dalam sel keluar dan jamur mengalami kematian (Septiadi et al., 2013).

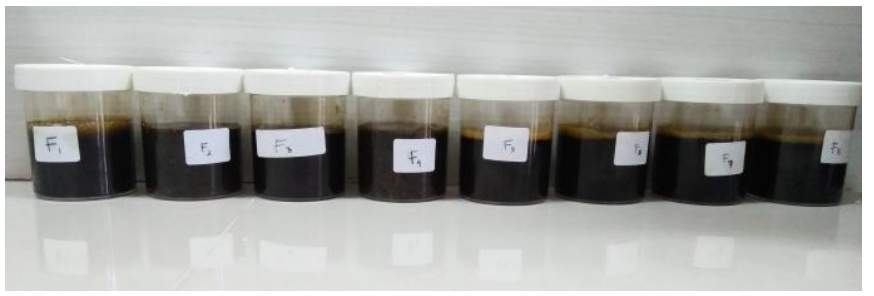

Gambar 1. Delapan formula ekstrak daun pacar air

Surfaktan yang digunakan dalam formulasi sediaan sampo ini merupakan surfaktan yang sering digunakan pada sediaan sampo di pasaran yaitu kombinasi dari surfaktan natrium lauril sulfat dan cocamide DEA. Natrium lauril sulfat merupakan surfaktan anionik yang pada konsentrasi $10 \%$ dapat memberikan daya busa yang baik namun mengiritasi kulit. Cocamide DEA merupakan surfaktan nonionik memiliki sifat tidak mengiritasi. Natrium lauril sulfat sering dikombinasikan dengan cocamide DEA untuk menghasilkan busa yang lebih ideal dan mencegah terjadinya proses penghilangan minyak yang berlebihan dari kulit kepala untuk menghindari iritasi 
kulit kepala (Emmawati et al., 2016). Bahan tambahan yang digunakan yaitu CMC sebagai pengental, metil paraben sebagai pengawet, asam sitrat sebagai pengatur $\mathrm{pH}$ dan mentol sebagai pewangi. Hasil kedelapan formula sampo ekstrak daun pacar air dapat dilihat pada gambar 1.

\section{Optimasi Formula Sampo Ekstrak Daun Pacar Air}

Tahap penelitian ini bertujuan untuk memperoleh formula optimum surfaktan sediaan sampo. Komponen yang divariasikan dalam optimasi ini yaitu natrium lauril sulfat dan cocamide DEA. Kedua komponen ini divariasikan karena berpengaruh pada parameter respon tinggi busa dan $\mathrm{pH}$ formula sampo. Nilai tinggi busa dan $\mathrm{pH}$ digunakan sebagai parameter untuk penentuan formula optimum sediaan sampo. Nilai respon untuk masing-masing run formula dapat dilihat pada tabel 3.

Tabel 3. Nilai Tinggi Busa dan $\mathrm{pH}$ Masing-Masing Run dalam Optimasi Formula

\begin{tabular}{lllll}
\hline & \multicolumn{2}{c}{ Komponen } & \multicolumn{2}{c}{ Respon } \\
\cline { 2 - 5 } Run & $\begin{array}{l}\text { A:Natrium } \\
\text { Lauril Sulfat }\end{array}$ & $\begin{array}{l}\text { B:Cocamide } \\
\text { DEA }\end{array}$ & $\begin{array}{l}\text { Uji Tinggi } \\
\text { Busa }\end{array}$ & $\begin{array}{l}\text { Uji } \\
\text { pH }\end{array}$ \\
\hline 1 & 5,5 & 15,5 & 11,9 & 5,87 \\
2 & 10 & 11 & 11,2 & 5,16 \\
3 & 3,25 & 17,75 & 10,3 & 5,82 \\
4 & 7,75 & 13,25 & 12,4 & 5,74 \\
5 & 1 & 20 & 9,3 & 6,21 \\
6 & 10 & 11 & 10,7 & 4,93 \\
7 & 1 & 20 & 9 & 6,17 \\
8 & 5,5 & 15,5 & 11,6 & 5,87 \\
\hline
\end{tabular}

\section{a. Tinggi Busa}

Uji tinggi busa bertujuan untuk menunjukkan kemampuan surfaktan membentuk busa. Pengukuran tinggi busa merupakan salah satu cara untuk pengendalian mutu suatu produk deterjen agar sediaan memiliki kemampuan yang sesuai dalam menghasilkan busa (Faizatun et al., 2008). Busa dari sampo merupakan hal yang sangat penting. Hal ini karena busa menjaga sampo tetap berada pada rambut, membuat rambut mudah dicuci, serta mencegah batangan-batangan rambut menyatu sehingga menyebabkan kusut (Malonda et al., 2017). Hasil uji tinggi busa dari delapan formula sediaan sampo memenuhi persyaratan tinggi busa yaitu 1,3-22 cm (Wilkinson dan Moore, 1982).

Nilai respon dari dua campuran komponen ditunjukkan dengan contour plot pada gambar 2 . Respon kombinasi tertinggi pada respon tinggi busa ditunjukkan pada area formula sampo dengan kombinasi 7,75:13,25 (natrium lauril sulfat : cocamide DEA). Respon tinggi busa yang paling rendah ditunjukkan pada formula dengan kombinasi 1:20.

Hasil analisis ANOVA menggunakan software ditunjukkan pada tabel 4. Dari hasil analisis tersebut, data yang diperoleh menunjukkan hasil yang baik. Berdasarkan model linear mixture, nilai $p$-value sebesar 0,0032 menunjukkan bahwa data tersebut normal $(p-$ value $<0,05$ ). Sementara untuk nilai lack of fit yaitu nilai untuk kesalahan murni pada data, menunjukkan hasil yang tidak signifikan yang berarti model yang diinginkan sesuai dan memiliki tingkat error yang kecil.

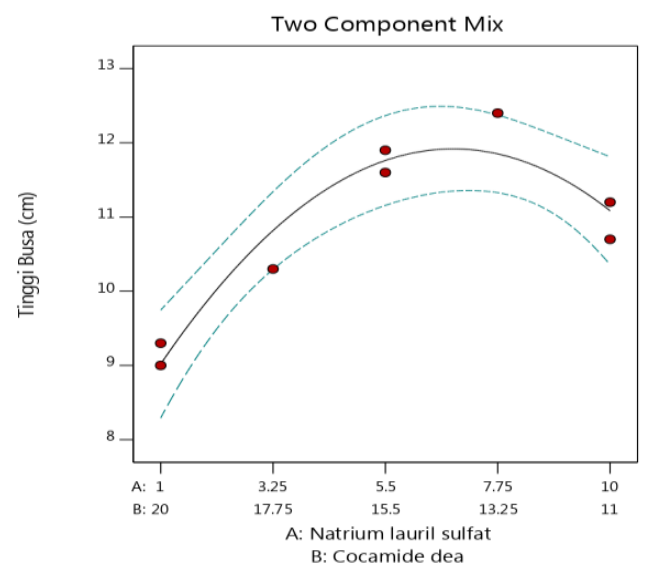

Gambar 2. Contour plot respon tinggi busa formula sampo

Tabel 4. Hasil Analisis ANOVA Respon Tinggi Busa dengan Perangkat Lunak Design Expert Versi 11.0.0.

\begin{tabular}{ll}
\hline Parameter & Nilai \\
\hline Model : linear mixture & 0,0032 \\
Residual : lack of fit & 0,1259 \\
\hline
\end{tabular}

Berdasarkan hasil analisis data, maka diperoleh persamaan Simplex Lattice Design (SLD) untuk respon tinggi busa seperti yang ditunjukkan pada persamaan 1.

$\mathrm{Y}=11,09(\mathrm{~A})+9,02(\mathrm{~B})+6,84(\mathrm{AB})$.

Keterangan :

$\mathrm{Y}=$ Respon tinggi busa

$\mathrm{A}=$ Konsentrasi natrium lauril sulfat

$\mathrm{B}=$ Konsentrasi cocamide DEA

Berdasarkan persamaan di atas, dapat dilihat bahwa setiap komponen memberikan respon positif terhadap tinggi busa sediaan sampo. Natrium lauril sulfat memiliki pengaruh paling besar terhadap tinggi busa. Hal ini dikarenakan natrium lauril sulfat merupakan surfaktan anionik sedangkan cocamide DEA merupakan surfaktan nonionik. Surfaktan anionik mempunyai daya pembentukan busa yang tinggi sedangkan produk-produk dari surfaktan nonionik cenderung menghasilkan busa yang relatif rendah. Secara umum, kemampuan pembentukan busa surfaktan meningkat dengan meningkatnya panjang rantai alkil pada gugus hidrofobik dan menurun dengan percabangan pada gugus hidrofobiknya. Pembentukan busa juga menurun dengan meningkatnya jumlah unit oksietilen pada gugus 
hidrofilik yang dimiliki surfaktan nonionik (Schramm 2005). Campuran komponen natrium lauril sulfat dan cocamide DEA juga menunjukkan respon yang positif sehingga dapat meningkatkan tinggi busa.

b. $\mathrm{pH}$

Uji $\mathrm{pH}$ bertujuan untuk mengetahui keamanan sediaan pada waktu digunakan. $\mathrm{pH}$ sampo yang terlalu asam maupun terlalu basa akan mengiritasi kulit kepala (Malonda et al., 2017). Berdasarkan hasil pengukuran $\mathrm{pH}$ dari delapan formula, penambahan agen pembusa akan menyebabkan peningkatan $\mathrm{pH}$ sebaliknya penurunan agen pembusa menyebabkan penurunan $\mathrm{pH}$. Berdasarkan persyaratan $\mathrm{pH}$ sampo yang telah ditetapkan dalam SNI No. 06-2692-1992 yaitu berkisar 5,0-9,0 maka dapat diketahui bahwa dari 8 formula hanya formula 6 yang tidak memenuhi syarat yaitu dengan $\mathrm{pH} 4,93$ namun nilai $\mathrm{pH}$ tersebut masih dapat ditoleransi karena masih memenuhi syarat pH kulit kepala yaitu 4,5-6,5 (Nurhikma et al., 2018).

Nilai respon dari dua campuran komponen ditunjukkan dengan contour plot gambar 3. Respon kombinasi tertinggi pada respon $\mathrm{pH}$ ditunjukkan pada area formula sampo dengan kombinasi natrium lauril sulfat:cocamide DEA sebesar 1:20. Respon pH yang paling rendah ditunjukkan pada area formula dengan kombinasi 10:11.

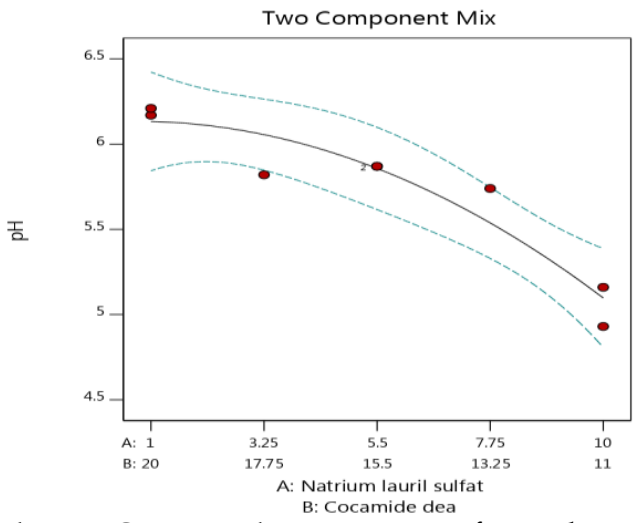

Gambar 3. Contour plot respon $\mathrm{pH}$ formula sampo

Hasil analisis ANOVA menggunakan software ditunjukkan pada tabel 5. Dari hasil analisis tersebut, data yang diperoleh menunjukkan hasil yang baik. Model linear mixture memiliki nilai $<0,05$ sehingga data dikatakan normal, sedangkan nilai lack of fit memiliki nilai >0,05 sehingga menunjukkan hasil yang tidak signifikan. Dengan demikian, dapat disimpulkan bahwa model yang diinginkan telah sesuai dan memiliki tingkat error yang kecil.

Tabel 5. Hasil Analisis ANOVA Respon $\mathrm{pH}$ dengan Perangkat Lunak Design Expert Versi 11.0.0.

\begin{tabular}{ll}
\hline Parameter & Nilai \\
\hline Model : linear mixture & 0,0012 \\
Residual : lack of fit & 0,0897 \\
\hline
\end{tabular}

Berdasarkan hasil analisis data, maka diperoleh persamaan Simplex Lattice Design (SLD) untuk respon $\mathrm{pH}$ seperti yang ditunjukkan pada persamaan 2 .

$\mathrm{Y}=5,10(\mathrm{~A})+6,13(\mathrm{~B})+0,9678(\mathrm{AB})$.

Keterangan :

$\mathrm{Y}=$ Respon $\mathrm{pH}$

$\mathrm{A}=$ Konsentrasi natrium lauril sulfat

$\mathrm{B}=$ Konsentrasi cocamide DEA

Berdasarkan persamaan diatas, dapat dilihat bahwa setiap komponen memberikan respon positif terhadap $\mathrm{pH}$ sediaan sampo. Cocamide DEA memiliki pengaruh paling besar terhadap $\mathrm{pH}$ yang kemudian diikuti dengan natrium lauril sulfat yang nilainya tidak terlalu berbeda jauh. Hal ini dikarenakan cocamide DEA memiliki $\mathrm{pH}$ 9,5-10,5 yang lebih tinggi dari natrium lauril sulfat dengan $\mathrm{pH}$ 7,5-8,5 (Rowe et al., 2009). Campuran komponen natrium lauril sulfat dan cocamide DEA juga menunjukkan respon yang positif sehingga dapat mempengaruhi $\mathrm{pH}$.

Berdasarkan hasil analisis data, komposisi komponen formula optimum yang diprediksi oleh perangkat lunak Design Expert versi 11.0.0. adalah natrium lauril sulfat sebesar $1,1863 \%$ dan cocamide DEA sebesar $19,814 \%$. Nilai prediksi tersebut digunakan untuk membuat formula optimum sediaan sampo. Sediaan sampo ekstrak daun pacar air dengan formula optimum dapat dilhat pada gambar 4. Adapun nilai prediksi respon yang akan didapatkan dari formula optimum sediaan sampo yaitu respon tinggi busa sebesar 9,2 cm dan respon $\mathrm{pH}$ sebesar 6,131. Nilai desirability yang didapatkan adalah sebesar 1,00 yang menandakan bahwa kemungkinan tercapainya hasil respon yang diinginkan sangat baik. Desirability merupakan nilai fungsi yang menunjukkan kemampuan program untuk memenuhi kriteria yang ditetapkan pada produk akhir. Nilai desirability yang semakin mendekati nilai 1,00 menunjukkan kemampuan program untuk menghasilkan produk yang dikehendaki semakin sempurna (Ramadhani, 2017). Diagram contour plot prediksi respon dari dua campuran komponen untuk uji tinggi busa, $\mathrm{pH}$ dan desirability dapat dilihat pada gambar 5 .

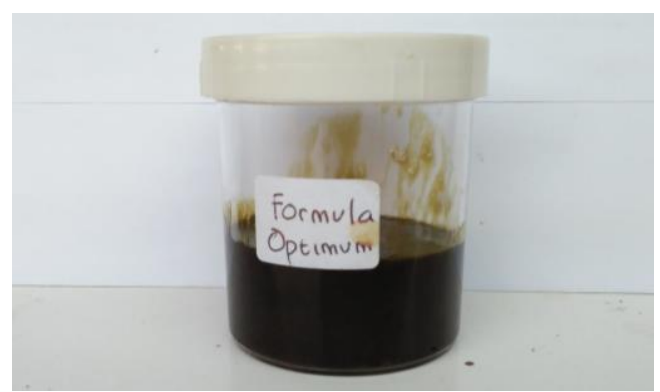

Gambar 4. Formula optimum ekstrak daun pacar air 


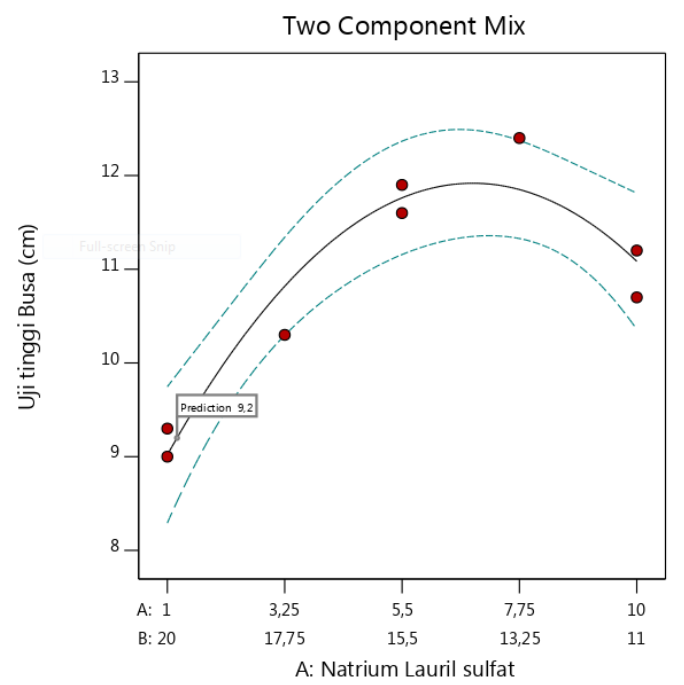

a.

B: Cocamide DEA

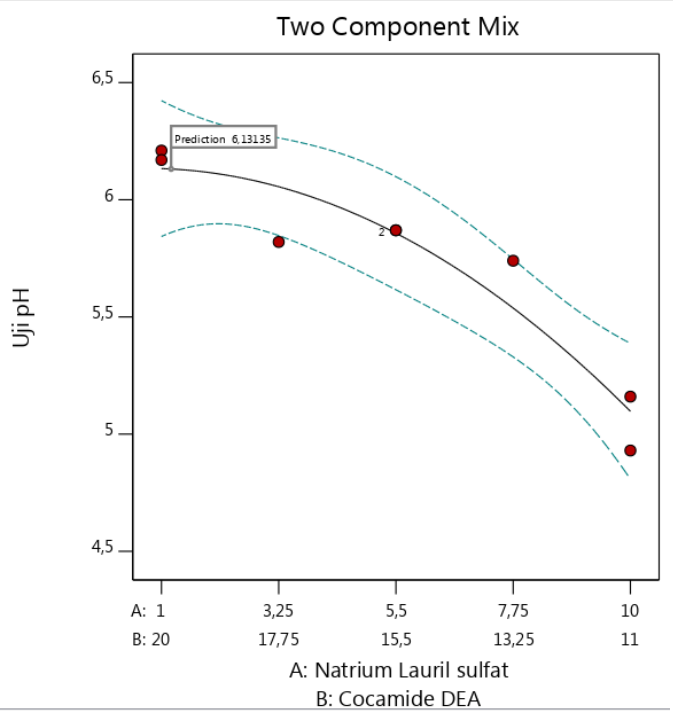

b.

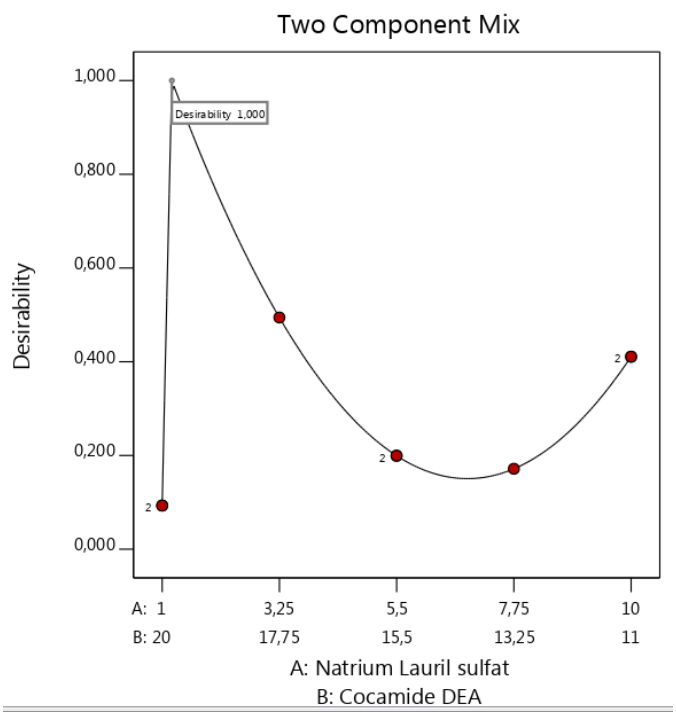

Gambar 5. Contour plot nilai prediksi respon dari campuran komponen natrium lauril sulfat dan cocamide DEA formula optimum sampo ekstrak daun pacar air. Keterangan: (a) Tinggi busa (b) $\mathrm{pH}$ (c) Desirability

\section{Verifikasi Formula Optimum}

Prediksi respon formula optimum yang telah diperoleh dari perangkat lunak Design Expert versi 11.0.0. selanjutnya dibandingkan dengan respon percobaan. Verifikasi formula optimum ini dilakukan untuk mengetahui adanya perbedaan bermakna antara respon yang diprediksikan software dengan respon percobaan. Analisis perbedaan ini menggunakan analisis statistik one sample t-test. Hasil analisis one sample t-test dapat dilihat pada tabel $\mathbf{6}$.

Tabel 6. Hasil One Sample t-test Formula Prediksi dibandingkan dengan Formula Optimum Percobaan.

\begin{tabular}{|c|c|c|c|c|}
\hline Respon & Prediksi & Percobaan & $\begin{array}{l}\text { Sig. } \\
2- \\
\text { tailed }\end{array}$ & Kesimpulan \\
\hline $\begin{array}{l}\text { Tinggi } \\
\text { busa }\end{array}$ & 9,2 & $\begin{array}{ll}10,025 & \pm \\
0,68 & \end{array}$ & 0,095 & $\begin{array}{l}\text { Tidak } \\
\text { berbeda }\end{array}$ \\
\hline $\mathrm{pH}$ & 6,131 & $6,12 \pm 0,02$ & 0,371 & $\begin{array}{l}\text { Tidak } \\
\text { berbeda }\end{array}$ \\
\hline
\end{tabular}

Berdasarkan hasil analisis tersebut, dapat diketahui bahwa respon tinggi busa dan $\mathrm{pH}$ prediksi menunjukkan hasil yang tidak berbeda secara signifikan dengan respon tinggi busa dan $\mathrm{pH}$ percobaan. Hal ini ditunjukkan oleh nilai p (sig. 2tailed) $\geq 0,05$. Hasil verifikasi ini memastikan bahwa optimasi dengan software dapat diterima.

\section{Evaluasi Sediaan Sampo ekstrak Daun Pacar Air}

Formula sampo ekstrak daun pacar air yang telah dibuat selanjutnya dilakukan evaluasi sediaan yang meliputi uji organoleptis, tinggi busa, $\mathrm{pH}$, dan akseptabilitas. Evaluasi pertama adalah uji organoleptis meliputi bentuk, bau dan warna. Berdasarkan uji organoleptis yang telah dilakukan didapatkan hasil bentuk sampo gel, warna hitam dan bau mentol menyengat.

Evaluasi kedua adalah uji tinggi busa. Uji tinggi busa bertujuan untuk menunjukkan kemampuan surfaktan membentuk busa. Hasil yang didapatkan pada uji tinggi busa yaitu $10,025 \pm 0,68 \mathrm{~cm}$. Hasil ini telah memenuhi persyaratan tinggi busa yaitu 1,3-22 cm (Wilkinson dan Moore, 1982).

Evaluasi ketiga yaitu uji $\mathrm{pH}$ yang bertujuan untuk mengetahui keamanan sediaan pada waktu digunakan. Berdasarkan hasil pengukuran didapatkan hasil pH sediaan sampo sebesar 6,12 $\pm 0,02$. Berdasarkan persyaratan $\mathrm{pH}$ sampo yang telah ditetapkan dalam SNI No. 06-2692-1992 yaitu berkisar 5,0-9,0 maka dapat diketahui hasil tersebut telah memenuhi syarat (Malonda et al., 2017).

Evaluasi terakhir yang dilakukan untuk formula sediaan sampo adalah uji akseptabilitas. Uji ini dilakukan untuk mengetahui seberapa besar sediaan sampo ekstrak daun pacar air yang dibuat dapat 
diterima oleh konsumen. Uji akseptabilitas ini meliputi penilaian warna, aroma, tekstur dan kekentalan. Sebanyak 20 responden diminta untuk menilai sediaan sampo ekstrak daun pacar air dengan skala penilaian 15. Hasil uji akseptabilitas sediaan sampo ekstrak daun pacar air dapat dilihat pada grafik yang disajikan dalam gambar 6 .

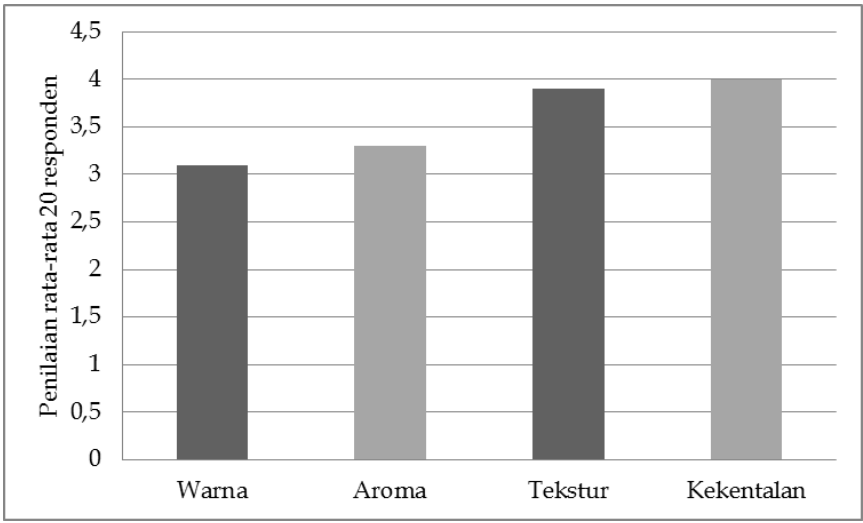

Gambar 6. Grafik hasil uji akseptabilitas sediaan sampo ekstrak daun pacar air

Dari rata-rata skor penilaian sukarelawan pada gambar 6, dapat diketahui bahwa parameter uji akseptabilitas warna, aroma, dan tekstur mendapat respon cukup disukai oleh sukarelawan, sedangkan untuk parameter kekentalan mendapatkan respon disukai. Dari keempat parameter uji akseptabilitas, parameter warna memiliki nilai akseptabilitas paling rendah namun masih dalam penilaian cukup disukai oleh sukarelawan, yaitu sebesar 3,1. Kemudian untuk parameter aroma mendapatkan nilai yaitu sebesar 3,3. Aroma dari sediaan cukup disukai oleh sukarelawan karena memiliki aroma mentol namun masih terlalu menyengat. Parameter tekstur mendapat nilai yaitu sebesar 3,9 yang cukup disukai oleh sukarelawan karena teksturnya yang lembut namun masih terdapat bulirbulir yang kurang homogen. Untuk parameter terakhir yaitu parameter kekentalan mendapat nilai yaitu sebesar 4. Parameter kekentalan disukai oleh sukarelawan yang memiliki kekentalan seperti gel yang sedikit cair.

\section{Kesimpulan}

Berdasarkan hasil penelitian dapat disimpulkan bahwa

1. Formula optimum sediaan sampo ekstrak daun pacar air memiliki komposisi yaitu 5\% ekstrak daun pacar air, 1,1863\% natrium lauril sulfat, 19,814\% cocamide DEA, 3\% CMC, 0,5\% asam sitrat, $0,5 \%$ metil paraben, $0,15 \%$ mentol dan akuades ditambahkan sampai $50 \mathrm{~mL}$.

2. Hasil evaluasi formula optimum sediaan sampo ekstrak daun pacar air yang meliputi uji organoleptis, tinggi busa, $\mathrm{pH}$ dan akseptabilitas telah memenuhi persyaratan, sehingga dapat dikatakan bahwa sediaan sampo ekstrak daun pacar air yang didapatkan merupakan sediaan yang baik.

\section{Daftar Pustaka}

Anitha, M., Hemapriya, J., Monica Roselin, E., Monisha, D. M., \& Swathy, S.R. (2015). Fungal Infection in Dandruff Afflicated Scalps on Medical Students. International Journal of Current Research, 7(12), 23712$23716 . \quad$ Retrieved from https://www.journalcra.com/sites/default/files/is sue-pdf/11842.pdf

Astuti, D.P., Patihul, H., \& Kusdi, H. (2017). Formulasi dan Uji Stabilitas Fisik Sediaan Gel Antiseptik Tangan Minyak Atsiri Bunga Lavender (Lavandula angustifolia Miller). Jurnal Farmaka Suplemen, 15(1), 176-84. Retrieved from http://jurnal.unpad.ac.id/farmaka/article/view/1 $\underline{3252}$

Balai Besar Litbang Tanaman Obat dan Obat Tradisional. (2011). Pedoman Umum Panen dan Pascapanen Tanaman Obat. Tawangmangu: Balai Besar Litbang Tanaman Obat dan Obat Tradisional.

Doughari, JH. (2006). Antimicrobial Activity of Tamarindus indica Linn. Tropical J Pharmaceu Res, 5(2), 597-603.

doi: http://doi.org/10.4314/tjpr.v5i2.14637

Emmawati, T., Sidharta, B., Puspita, O.E., \& Syafitri, M. H. (2016). Optimasi Formula dan Teknik Pembuatan Sampo Susu Sapi Segar Menggunakan Kombinasi Surfactant dan Co-Surfactant. Majalah Kesehatan FKUB, 3(2), 93-111. Retrieved from https://majalahfk.ub.ac.id/index.php/mkfkub/arti cle/view/95/88

Faizatun, Kartiningsih, \& Liliyana. (2008). Formulasi Sediaan Sampo Ekstrak Bunga Chamomile dengan Hidroksi Propil Metil Selulosa Sebagai Pengental. Jurnal Ilmu Kefarmasian Indonesia. 6(1), 15-22. Retrieved from http://jifi.farmasi.univpancasila.ac.id/index.php/ji fi/article/view/412/288

Indrawati, T., \& Nelly, W. (2011). Stabilitas Sabun Cair Wajah yang Mengandung Susu Kambing dengan Variasi Konsentrasi Kokamide DEA. Jurnal Ilmu Kefarmasian Indonesia, 9(1), 8-13. Retrieved from https://www.google.com/url?sa=t\&rct=j\&q=\&esrc $=$ s\&source $=$ web\&cd $=\& \mathrm{cad}=$ rja\&uact $=8 \& v e d=2 \mathrm{ahU}$ KEwi8leOAtMLtAhU1meYKHf_mCgAQFjAAegQI BRAC\&url=http $\% 3 \mathrm{~A} \% 2 \mathrm{~F} \% 2 \mathrm{Fjifi.farmasi.univpancas}$ ila.ac.id \%2Findex.php \%2Fjifi\%2Farticle\%2Fdownloa d\%2F313\%2F223\&usg=AOvVaw1_71nTeRSHOxShg WYeMO7o

Iswanti, D.A. (2009). Uji Aktivitas Antibakteri Fraksi NHeksan, Fraksi Etil Asetat, dan Fraksi Etanol 96\% Daun Ekor Kucing (Acalypha Hispida Burm. F) Terhadap 
Bakteri Staphylococcus aureus ATCC 25923 Secara Dilusi. (Unpublished master thesis). Fakultas Farmasi Universitas Setia Budi, Surakata.

Maesaroh, I. (2016). Formulasi Sediaan Sampo Jelly Anti Ketombe dari Ekstrak Kangkung (Ipomoea aquatica Forssk.). Jurnal Ilmiah Kopertis Wilayah IV, 1(1), 81-87. Retrieved from https://id.scribd.com/document/366152367/81-87Formulasi-Sediaan-pdf

Mahataranti, N., Astuti, I.Y., \& Asriningdhiani, B. (2012). Formulasi Shampo Antiketombe Ekstrak Etanol Seledri (Apium Graveolens L.) dan Aktivitasnya Terhadap Jamur Pityrosporum ovale. Jurnal Pharmacy, 9(2), 128-138. doi: https://dx.doi.org/10.30595/pji.v9i2.710

Malonda, T.C., Yamlean, P. V. Y.\& Citraningtyas, G. (2017). Formulasi Sediaan Sampo Antiketombe Ekstrak Daun Pacar Air (Impatiens Balsamina L.) dan Uji Aktivitasnya Terhadap Jamur Candida Albicans Atcc 10231 Secara In Vitro. PHARMACON Jurnal Ilmiah Farmasi - UNSRAT, 6(4), 97-109. doi: https://doi.org/10.35799/pha.6.2017.17725

Marpaung, M.P., \& Romelan. (2018). Analisis Jenis dan Kadar Saponin Ekstrak Metanol Daun Kemangi (Ocimum basilicum L.) dengan Menggunakan Metode Gravimetri. Jurnal Farmasi Lampung, 7(2), 8186. doi: https://doi.org/10.37090/jfl.v7i2.57

Naitullah, N., Faisal J., Frengki \& Maryulia, D. (2014). Pengaruh Pemberian Ekstrak Etanol Daun Pacar Air (Impaiens balsamina Linn) Terhadap Pertumbuhan Candida albicans Secara In Vitro. Jurnal Medika Veterinaria, 8(2), 125-127. Retrieved from https://etd.unsyiah.ac.id/index.php?p=show_detai 1\&id=16555

Nurhikma, E., Dewi A., \& Selfyana, A.T. (2018). Formulasi Sampo Antiketombe Dari Ekstrak Kubis (Brassica oleracea Var. Capitata L.) Kombinasi Ekstrak Daun Pandan Wangi (Pandanus amaryllifolius Roxb). Jurnal Mandala Pharmacon Indonesia, 4(1), 61-67. doi: https://doi.org/10.35311/jmpi.v4i1.25

Ramadhani, R.A. (2017). Review Pemanfaatan Design Expert Untuk Optimasi Komposisi Campuran Minyak Nabati Sebagai Bahan Baku Sintesis Biodiesel. Jurnal Teknik Kimia Dan Lingkungan, 1(1) 11-16. doi: http:/ / dx.doi.org/10.33795/jtkl.v1i1.5

Robinson, T. (1995). Kandungan Organik Tumbuhan Tinggi (Edisi ke-6). (Terjemahan oleh Kokasih Padmawinata). Bandung: ITB

Rowe, R.C., Sheskey, P.J., \& Quinn, M.E. (2009). Handbook of Pharmacuetical Exipients (Sixth Edition). USA: Pharmaceutical Press.

Schramm, LL. (2005). Emulsions, Foams, and Suspensions: Fundamentals and Applications. Weinheim: WILEYVCH Verlag GmbH \& Co. KGaA.
Septiadi, T., Priggenies, D. \& Radjasa, O.K. (2013). Uji Fitokimia dan Aktivitas Antijamur Ektrak Teripang Keling (Holoturia atra) Dari Pantai Bandengan Jepara Terhadap Jamur Candida albicans. Journal of Marine Research, 2(2), 76-84. doi: https://doi.org/10.14710/imr.v2i2.2355

Simaremare, E.S. (2014). Skrining Fitokimia Ekstrak Etanol Daun Gatal (Laportea decumana (Roxb.) Wedd). PHARMACY, 11(1), 98-107. doi: https://dx.doi.org/10.30595/pji.v11i1.855

Sitompul M. B., Yamlean, P.V.Y., \& Kojong, N.S. (2016). Formulasi dan Uji Aktivitas Sediaan Sampo Antiketombe Ekstrak Etanol Daun Alamanda (Allamanda Cathartica L.) Terhadap Pertumbuhan Jamur Candida Albicans Secara In Vitro. PHARMACON Jurnal Ilmiah Farmasi - UNSRAT, 5(3), 122-130. doi: https://doi.org/10.35799/pha.5.2016.12946

Sudewo, B. (2009). Buku Pintar Hidup Sehat Cara Mas Dewo. Jakarta: Argo Media Pustaka.

Suharmiati \& Herti, M, (2003). Khasiat dan Manfaat Jati Belanda. Surabaya: Agromedia Pustaka.

Sulistyaningrum, F., Muryati, S., \& Setyani, W. (2008). Uji Ativitas Antijamur Fraksi N-Heksan, Etil Asetat dan Air Daun Pacar Air (Impatiens balsamina Linn.) terhadap Pertumbuhan Candida albicans ATCC 10231. (Unpublished master thesis). Sekolah Tinggi Ilmu Farmasi Yayasan Pharmasi, Semarang.

Susanto, A. (2008). Sistem Informasi Manajemen. Bandung: Lingga Jaya.

Wilkinson, J.B. \& Moore, R.J. (1982). Harry's Cosmeticology (Seventh Edition). London: George Godwin. 